\title{
Weed Management in Corn ${ }^{1}$
}

\author{
J. A. Ferrell, G. E. MacDonald, and P. Devkota ${ }^{2}$
}

Successful weed control is essential for economical corn production in Florida. Weeds reduce corn yields by competing for moisture, nutrients, and light during the growing season and interfere with harvest. Producing a good corn crop is only half the battle and will not be profitable unless the corn can be harvested. Late-season weeds can result in excessive yield loss and inefficient equipment operation and provide a source of weed seed for the following season. Weeds can be controlled in corn; however, this requires good management practices in all phases of corn production.

\section{Crop Rotations}

Crop rotations help to reduce weed problems in corn or other subsequent crops in the rotation. Another benefit is reduction of insects, diseases, and nematodes in corn and succeeding crops.

\section{Crop Competition}

Crop competition is one of the most significant but often overlooked tools in weed control. A good stand of corn, which emerges rapidly and uniformly and shades the middles early, is very important in reducing weed competition. This involves utilizing good management practices, such as choosing a well-adapted hybrid, ensuring good fertility, maintaining proper soil $\mathrm{pH}$, and using adequate plant populations. These good management practices are necessary for controlling weeds and producing high yield. The plant that emerges and grows most rapidly is usually the plant that will have the competitive advantage; therefore, everything should be done to ensure that the corn has this competitive advantage instead of the weeds.

\section{Know Your Weeds}

Know your weeds and choose an appropriate and effective herbicide for the specific weed problem. Generally, for preplant and preemergence applications, the weed problem must be anticipated based on the previous year's weed history because the weeds have not emerged at the time of application. Observe the field in the fall and record which weeds are present and where they occur. These "weed maps" can refresh your memory and help in herbicide purchasing decisions in the following spring. Once the weed problems have been identified, Tables 4 and 5 can be used to determine the most effective herbicide(s).

\section{Cultivation}

Cultivation is still a good and economical means of weed control. However, few benefits other than weed control have been attributed to it. Disadvantages of cultivation include

1. This document is SS-AGR-02, one of a series of the Agronomy Department, UF/IFAS Extension. Original publication date January 2000. Revised April 2020. Visit the EDIS website at https://edis.ifas.ufl.edu for the currently supported version of this publication.

2. J. A. Ferrell, associate professor, Agronomy Department; G. E. MacDonald, professor, Agronomy Department; and P. Devkota, assistant professor, weed science, UF/IFAS West Florida Research and Education Center; UF/IFAS Extension, Gainesville, FL 32611. Original written by J. A. Ferrell, G. E. MacDonald, and B. J. Brecke; revised by P. Devkota.

The use of trade names in this publication is solely for the purpose of providing specific information. UF/IFAS does not guarantee or warranty the products named, and references to them in this publication do not signify our approval to the exclusion of other products of suitable composition. All chemicals should be used in accordance with directions on the manufacturer's label. Use herbicides safely. Read and follow directions on the manufacturer's label.

The Institute of Food and Agricultural Sciences (IFAS) is an Equal Opportunity Institution authorized to provide research, educational information and other services

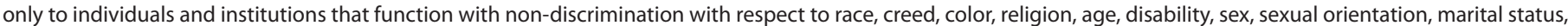

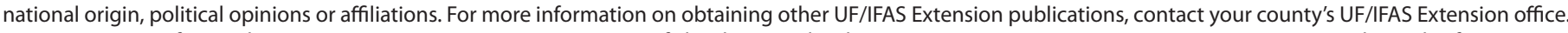
U.S. Department of Agriculture, UF/IFAS Extension Service, University of Florida, IFAS, Florida A \& M University Cooperative Extension Program, and Boards of County Commissioners Cooperating. Nick T. Place, dean for UF/IFAS Extension. 
enhanced soil erosion, disruption of corn roots, greater moisture loss from soil, and increased weed seed near the surface. If herbicides have resulted in good weed control, then the need to cultivate is questionable.

\section{Herbicides}

Herbicides are one of the most effective tools for successful weed control in corn. Preplant or preemergence applications combined with the previously discussed management practices are important for ensuring that corn has the initial competitive advantage. If corn is taller than the weeds, then postemergence directed applications can be utilized to extend the weed control through the season. This option is not available if the weeds are as tall as the corn. Late-season, over-the-top applications can aid in harvest efficiency. However, this will not be needed in most cases if good weed control is achieved throughout the season and the corn is harvested when mature.

The herbicides in Table 1, Table 2, and Table 3 have performed well in UF/IFAS research. When choosing an herbicide, consider the crop that will follow in a rotation and the risk of herbicide carryover and injury. Read the label and follow all instructions and precautions. Accurate sprayer calibration is extremely important because insufficient rates may not provide adequate weed control and excessive rates may injure the crop or result in carryover and injury to succeeding crops. Herbicides, like any pesticide, should be handled with care. Store herbicides behind locked doors in the original containers with the label intact. Keep them separated from seed, fertilizers, and other pesticides.

\section{Weed Control in No-Till Corn}

No-till production practices virtually eliminate the effect of cultivation, thus placing greater importance on effective chemical weed control.

Chemical weed control in no-till corn is similar to that in conventional corn with two basic differences:

1. Existing vegetative growth must be killed or suppressed with an herbicide at or before planting by burndown application. See Table 1 for these herbicides.

2. Herbicides requiring mechanical soil incorporation cannot be effectively used. All other herbicides listed for preemergence or postemergence application below can be used in no-till corn just as in conventional corn. 
Table 1. Burndown herbicides for no-till corn.

\begin{tabular}{|c|c|c|}
\hline $\begin{array}{l}\text { Trade Name and Broadcast } \\
\text { Rate/Acre of Commercial } \\
\text { Product }\end{array}$ & Common Name & Remarks \\
\hline $\begin{array}{l}\text { Gramoxone Inteon SL } 2.0 \\
1-2 \text { qt }\end{array}$ & paraquat & $\begin{array}{l}\text { Higher rate should be used for woody plants or sod if they are present. A proper } \\
\text { surfactant must be added. Apply in } 20-30 \text { gallons of solution per acre. Some regrowth } \\
\text { from rye, oats, or wheat may occur after treatment. This may vary with small grain } \\
\text { species, variety, and stage of growth. For these reasons, it is suggested that an } \\
\text { application should be made } 10-14 \text { days prior to planting. If regrowth occurs, retreat } \\
\text { at planting or before emergence of the corn. Good coverage is essential for effective } \\
\text { control. Including 2,4-D at } 1 \text { qt/A will improve control of wild radish and cutleaf evening } \\
\text { primrose. }\end{array}$ \\
\hline $\begin{array}{l}\text { Sharpen } \\
2 \mathrm{oz} / \mathrm{A}\end{array}$ & saflufenacil & $\begin{array}{l}\text { For burndown and short-lived residual of many broadleaf weed species. Sharpen } \\
\text { will not control large wild radish or cutleaf evening primrose. A methylated seed oil } \\
\text { adjuvant is essential for maximum effectiveness. Do not apply more than } 6 \text { oz/A/yr. } \\
\text { Treated corn can be harvested for silage after } 80 \text { days. }\end{array}$ \\
\hline $\begin{array}{l}\text { Verdict or Integrity } \\
10-12 \mathrm{oz} / \mathrm{A}\end{array}$ & $\begin{array}{l}\text { saflufenacil + } \\
\text { dimethenamid }\end{array}$ & $\begin{array}{l}\text { Similar to Sharpen, but with improved preemergence grass control due to the presence } \\
\text { of dimethenamid. Do not apply more than } 25 \text { oz/A/yr. Can be harvested for silage } 80 \\
\text { days after application. }\end{array}$ \\
\hline $\begin{array}{l}\text { Several } \\
1-2 \text { qt }\end{array}$ & glyphosate & $\begin{array}{l}\text { Lower rate should be used on annual weeds and higher rate should be used on } \\
\text { perennial weeds. Apply in 10-20 gallons of water. See label for additional information. } \\
\text { For control of most annual weeds. Rate of kill may be slow during cool weather. Will not } \\
\text { supply residual control and should be used in conjunction with a residual herbicide. } \\
\text { Choose the residual herbicide or combination of herbicides based on anticipated } \\
\text { weeds. Tank mixes with certain residual herbicides such as atrazine may result in some } \\
\text { reduction of activity. Consult label for appropriate tank mixes. Including 2,4-D at } 1 \text { qt/A } \\
\text { will improve control of wild radish and cutleaf evening primrose. }\end{array}$ \\
\hline
\end{tabular}


Table 2. Herbicide options for weed management in corn.

\begin{tabular}{|c|c|c|}
\hline $\begin{array}{l}\text { Trade Name and } \\
\text { Broadcast Rate/ } \\
\text { Acre of Commercial } \\
\text { Product }\end{array}$ & Common Name & Remarks \\
\hline \multicolumn{3}{|r|}{ PREPLANT } \\
\hline $\begin{array}{l}\text { AAtrex } 4 \mathrm{~L}^{1} \\
\quad 2-4 \mathrm{pt} \\
\text { (or several } \\
\text { formulations) }\end{array}$ & $\begin{array}{l}\text { atrazine } \\
(1-2 \mathrm{lb} \text { ai })\end{array}$ & $\begin{array}{l}\text { Controls most broadleaf weeds and some grasses. Tank-mix with a grass herbicide for broader- } \\
\text { spectrum control. Do not use more than } 2.5 \mathrm{lb} \text { ai/A/year. }\end{array}$ \\
\hline \multicolumn{3}{|r|}{ PREEMERGENCE } \\
\hline $\begin{array}{l}\text { AAtrex } 4 \mathrm{~L}^{1} \\
2-4 \mathrm{pt} \\
\text { (or several } \\
\text { formulations) }\end{array}$ & $\begin{array}{c}\text { atrazine } \\
(1.0-2 \mathrm{lb} \text { ai) }\end{array}$ & $\begin{array}{l}\text { Good broadleaf weed control; less effective on grasses. Use the lower rate on light sandy soils. } \\
\text { Under dry conditions, a shallow cultivation may improve control. Do not graze or feed treated } \\
\text { forage to livestock for } 21 \text { days after application. Do not use more than } 2.5 \mathrm{lb} \text { ai/A/year. }\end{array}$ \\
\hline $\begin{array}{l}\text { Simazine } 4 \mathrm{~L} \\
\text { (several trade names) } \\
1-2 \mathrm{qt}\end{array}$ & simazine & $\begin{array}{l}\text { Refer to herbicide table and label for specific product. Similar to atrazine, but requires more } \\
\text { rainfall for activation and is generally less effective in control of certain broadleaf weeds. Good } \\
\text { control of crabgrass and fall panicum. }\end{array}$ \\
\hline $\begin{array}{l}\text { Outlook or Slider } \\
12-18 \mathrm{oz}\end{array}$ & S-dimethenamid & $\begin{array}{l}\text { Similar in control to metolachlor. Application rate depends on soil texture and organic matter } \\
\text { percentage-see product label for specific details. May be harvested for silage } 40 \text { days or more } \\
\text { after application. Many premix products available that also contain atrazine. }\end{array}$ \\
\hline $\begin{array}{l}\text { Axiom } \\
13-22 \mathrm{oz} / \mathrm{A}\end{array}$ & $\begin{array}{l}\text { flufenacet }+ \\
\text { metribuzin }\end{array}$ & $\begin{array}{l}\text { Provides annual grass and small-seeded broadleaf control similar to metolachlor. Specific use rate } \\
\text { depends on soil texture and organic matter. Corn should be planted 1-1.5 in deep. Can be tank- } \\
\text { mixed with atrazine for improved control of broadleaf weeds. Corn and soybeans can be planted } \\
\text { at any time after an application of Axiom. A 12-month rotation restriction exists for rye, sorghum, } \\
\text { wheat, cotton, peanuts, and tobacco. }\end{array}$ \\
\hline $\begin{array}{l}\text { Dual II Magnum or } \\
\text { Dual Magnum } 1-1.3 \mathrm{pt} \\
\text { or } \\
\text { Stalwart, Parallel, } \\
1-1.3 \mathrm{pt}\end{array}$ & $\begin{array}{l}\text { S-metolachlor } \\
\text { or } \\
\text { metolachlor }\end{array}$ & $\begin{array}{l}\text { Controls most annual grasses (except Texas panicum) and certain broadleaf weeds. Fair to good } \\
\text { control of yellow nutsedge. Under cool, wet weather conditions, stunting or crop injury expressed } \\
\text { as malformed, knotted, twisted top growth may occur. Corn normally outgrows early-season } \\
\text { injury. Metolachlor may be tank-mixed with atrazine or simazine. Metolachlor can be applied to } \\
\text { corn up to } 40 \text { in tall. Available in several premixes with atrazine. The metolachlor formulations } \\
\text { (Parallel, Stalwart, others) often will not provide the same duration of control as S-metolachlor } \\
\text { formulations. }\end{array}$ \\
\hline \multicolumn{3}{|r|}{ POSTEMERGENCE } \\
\hline $\begin{array}{l}\text { Aim } 2 \text { EC } \\
0.5-1 \text { oz/A }\end{array}$ & carfentrazone & $\begin{array}{l}\text { For the control of pigweed, annual morning glory species (except smallflower), and tropical } \\
\text { spiderwort. Can be applied over the top of corn until the V8 stage of growth. Aim will cause } \\
\text { crop injury in the form of leaf speckling and necrosis, but this injury will not affect yield. Use in } \\
\text { combination with a crop oil concentrate at } 1 \% \mathrm{v} / \mathrm{v} \text { ( } 1 \text { gal } / 100 \text { gals). Aim can be tank-mixed with } \\
\text { glyphosate (GR corn hybrids only), 2,4-D, atrazine, and Accent. }\end{array}$ \\
\hline $\begin{array}{l}\text { Accent 75DF (and } \\
\text { several other products } \\
\text { and formulations) }\end{array}$ & nicosulfuron & $\begin{array}{l}\text { Single Application } \\
\text { Controls many annual and perennial grasses, including johnsongrass. DO NOT apply to corn } \\
\text { treated with Counter insecticide due to severe crop injury or mortality. Can be applied over the } \\
\text { top of corn up to } 20 \text { in tall or before the V6 stage (whichever is more restrictive) and post-directed } \\
\text { up to } 36 \text { in tall. A nonionic surfactant }(0.25 \% \mathrm{v} / \mathrm{v}) \text { or crop oil concentrate }(1 \% \mathrm{v} / \mathrm{v}) \text { is required. } \\
\text { Refer to manufacturer's label for additive rates. Do not apply within } 7 \text { days to corn treated with } \\
\text { foliar-applied organophosphate insecticides or with herbicides containing bentazon or } 2,4- \\
\text { D. DO NOT apply organophosphate insecticides within } 3 \text { days after applying Accent. Refer to } \\
\text { manufacturer's label for sprayer cleanup. DO NOT apply within } 30 \text { days of harvest. } \\
\text { Split Application } \\
\text { For hard-to-control weeds, two applications can be applied } 14-28 \text { days apart. Follow all } \\
\text { precautions listed for single application. DO NOT exceed the maximum rate usage for the year. } \\
\text { Refer to specific product label for further direction. }\end{array}$ \\
\hline $\begin{array}{l}\text { Atrazine or AAtrex } \\
\qquad 1-2 \text { qt }\end{array}$ & atrazine & $\begin{array}{l}\text { Addition of a crop oil at the rate of } 1 \mathrm{qt} / \mathrm{A} \text { provides quicker kill of weeds. Apply before weed } \\
\text { height exceeds } 2 \text { in and corn height exceeds } 12 \mathrm{in.} \text { Most effective on broadleaf weeds. Do not } \\
\text { apply with fluid fertilizer. Do not exceed } 2.5 \mathrm{lb} \text { ai/A/yr. }\end{array}$ \\
\hline $\begin{array}{l}\text { Banvel, Clarity, Vision } \\
\text { 0.5-1.0 pt }\end{array}$ & dicamba & $\begin{array}{l}\text { Good control of broadleaf weeds. Can be applied broadcast over the top at } 1 \text { pt from corn } \\
\text { emergence to V } 5 \text { or } 8 \text { in. For } 8 \text { - to } 36 \text {-in tall corn, apply only } 0.5 \text { pt. Do not apply within } 15 \text { days } \\
\text { before tassel emergence. Do not graze or harvest for dairy or beef feed prior to milk stage. Avoid } \\
\text { spray drift to nearby sensitive crops. The addition of a surfactant is optional-do not use crop oils. }\end{array}$ \\
\hline
\end{tabular}




\begin{tabular}{|c|c|c|}
\hline $\begin{array}{l}\text { Trade Name and } \\
\text { Broadcast Rate/ } \\
\text { Acre of Commercial } \\
\text { Product }\end{array}$ & Common Name & Remarks \\
\hline $\begin{array}{l}\text { Basagran } \\
0.75-1.5 \text { qt }\end{array}$ & bentazon & $\begin{array}{l}\text { Controls certain broadleaf weeds and yellow nutsedge. To control yellow nutsedge, two } \\
\text { applications 7-10 days apart are generally required. Rate depends on weed species and size. } \\
\text { Check the label. Do not apply to corn that has been subjected to stress. Do not mix with other } \\
\text { pesticides or fertilizers. Add crop oil at } 1 \mathrm{qt} / \mathrm{A} \text {. }\end{array}$ \\
\hline $\begin{array}{l}\text { Buctril 4EC } \\
0.5-1.0 \mathrm{pt}\end{array}$ & bromoxynil & $\begin{array}{l}\text { Controls cocklebur, bristly starbur, and certain other broadleaf weeds when less than } 3 \text { in tall. } \\
\text { Adjust rate according to weed size and crop age. Applications of Buctril often result in leaf } \\
\text { burning on corn. This injury generally lasts } 7 \text { days and does not affect yield. }\end{array}$ \\
\hline $\begin{array}{l}\text { Callisto } \\
3.0 \mathrm{oz}\end{array}$ & mesotrione & $\begin{array}{l}\text { Applications may be made up to } 30 \text { in or } 8 \text {-leaf stage and should contain crop oil concentrate } \\
\text { with } 28 \% \text { nitrogen or ammonium sulfate. Callisto can be applied sequentially, more than } 14 \\
\text { days apart, if needed. Do not exceed } 6.0 \mathrm{fl} \mathrm{oz/A/yr} \mathrm{if} \mathrm{applied} \mathrm{postemergence,} \mathrm{or} 7.4 \mathrm{fl} \text { oz/A/yr if } \\
\text { applied preemergence and postemergence. Do not apply in combination with organophosphate } \\
\text { insecticides. Some temporary bleaching may occur after application. }\end{array}$ \\
\hline $\begin{array}{l}\text { 2,4-D amine } \\
0.5-1 \mathrm{pt} / \mathrm{A}\end{array}$ & $2,4-D$ & $\begin{array}{l}\text { May be applied to corn that is } 5 \text { to } 8 \text { in high. Must be applied as a directed spray after corn is } 8 \\
\text { in or slight to moderate injury will result. If an herbicide with this mode of action is desirable but } \\
\text { corn injury is a concern, Status herbicide would be a better choice. No adjuvant is needed. }\end{array}$ \\
\hline $\begin{array}{l}\text { Status } \\
5-10 \mathrm{oz}\end{array}$ & $\begin{array}{l}\text { dicamba }+ \\
\text { diflufenzopyr }+ \\
\text { isoxadifen }\end{array}$ & $\begin{array}{l}\text { For control of broadleaf weeds. Can be applied to } 4 \text { - to } 36 \text {-in-tall corn. Corn is more tolerant to } \\
\text { Status than other dicamba- or } 2,4 \text {-D-containing products. Best if applied with nonionic surfactant } \\
(0.25 \% \mathrm{v} / \mathrm{v}) \text {. Can be mixed with glyphosate or Liberty } 280 \text { (at } 5 \mathrm{oz} / \mathrm{A} \text { ) if tolerant hybrids have been } \\
\text { planted. Avoid drift to sensitive crops. }\end{array}$ \\
\hline $\begin{array}{l}\text { Dual II Magnum, Dual } \\
\text { Magnum } \\
1.0 \mathrm{pt}\end{array}$ & S-metolachlor & $\begin{array}{l}\text { Dual + atrazine should be applied before weeds are past 2-leaf stage and before corn is } 5 \text { in tall. } \\
\text { Applications of Dual Magnum may result in temporary leaf burning on corn. Dual will not control } \\
\text { emerged weeds. }\end{array}$ \\
\hline $\begin{array}{l}\text { Laudis } \\
3 \mathrm{fl} \mathrm{oz/A}\end{array}$ & tembotrione & $\begin{array}{l}\text { Laudis provides excellent postemergence control (with soil residual activity) of several grass } \\
\text { and broadleaf weeds. Tank mixes with glyphosate improve control of pigweeds, ragweed, and } \\
\text { morning glory. Laudis can be applied from corn emergence to V8 growth stage. A maximum of } \\
6 \text { oz/A can be applied annually. Laudis should be applied with a crop oil or methylated seed oil } \\
\text { adjuvant. Small grains can be planted within } 4 \text { months of application. }\end{array}$ \\
\hline $\begin{array}{c}\text { Pendimethalin } 3.3 \\
1.8-2.4 \mathrm{pt} \\
\text { or } \\
\text { Prowl } \mathrm{H}_{2} \mathrm{O} \\
2 \mathrm{pt} \\
+ \\
\text { AAtrex or Atrazine }{ }^{1} \\
\text { (several formulations) }\end{array}$ & $\begin{array}{l}\text { pendimethalin } \\
\stackrel{+}{+} \\
\text { atrazine }\end{array}$ & $\begin{array}{l}\text { Pendimethalin + atrazine should be applied before the corn is in the } 4 \text {-leaf stage and before } \\
\text { weeds emerge. Pendimethalin } 3.3 \text { requires irrigation or rainfall within } 7 \text { days to activate. Prowl } \\
\mathrm{H}_{2} \mathrm{O} \text { is more tolerant to dry conditions after application. }\end{array}$ \\
\hline $\begin{array}{c}\text { Sandea } \\
0.67-1.33 \mathrm{oz}\end{array}$ & halosulfuron & $\begin{array}{l}\text { Controls yellow and purple nutsedge. Can be applied over the top from spike stage through layby } \\
\text { stage. Use higher rates for nutsedge and larger weeds. The use of a nonionic surfactant or crop oil } \\
\text { is recommended. May be applied in a split application but do not exceed } 2.67 \text { oz/A/year. }\end{array}$ \\
\hline $\begin{array}{l}\text { Pendimethalin } 3.3 \\
1.8-2.4 \mathrm{pt} \\
\text { or } \\
\text { Prowl } \mathrm{H}_{2} 0 \\
2 \mathrm{pt}\end{array}$ & pendimethalin & $\begin{array}{l}\text { Apply postplant and incorporate for late-season control of annual grasses and certain small- } \\
\text { seeded broadleaf weeds. Apply after corn is } 4 \text { in tall but before the last cultivation. Do not apply } \\
\text { if pendimethalin was used as a preemergence application. Existing weeds must be killed before } \\
\text { application. Incorporate with either: (1) sweeps or rolling cultivator or (2) rainfall or irrigation as } \\
\text { soon as possible after application. }\end{array}$ \\
\hline $\begin{array}{l}\text { Resource } \\
2.0-4.0 \mathrm{fl} \mathrm{oz}\end{array}$ & flumiclorac & $\begin{array}{l}\text { Mix with Roundup for increased broadleaf control in transgenic Roundup Ready corn. Tall ivyleaf } \\
\text { and entire-leaf morning glory control is enhanced by adding Resource to glyphosate. Do not } \\
\text { apply before the 2-leaf or after the } 10 \text {-leaf stage of corn development. }\end{array}$ \\
\hline $\begin{array}{c}\text { Resolve } Q \\
1.25 \mathrm{oz} / \mathrm{A}\end{array}$ & $\begin{array}{l}\text { rimsulfuron }+ \\
\text { thifensulfuron }+ \\
\text { crop safener }\end{array}$ & $\begin{array}{l}\text { Apply postemergence to corn that is up to } 20 \text {-in tall for the control of many annual grasses } \\
\text { and broadleaf weeds. Will also provide some residual control. Do not apply to corn taller than } \\
20 \text {-in or exhibiting } 7 \text { or more leaf collars. Use in combination with a NIS at } 0.25 \% \text { v/v or COC at } \\
1 \% \text { v/v + ammonium nitrogen fertilizer ( } 2 \text { qt/A UAN or } 2 \mathrm{lb} / \mathrm{A} \text { AMS). Can be tank-mixed with } \\
\text { atrazine, glyphosate (RR corn), or Liberty (LL corn). Do not apply Resolve Q to corn that has been } \\
\text { previously treated with an OP insecticide, such as Counter, Lorsban, or Thimet. }\end{array}$ \\
\hline
\end{tabular}




\begin{tabular}{|c|c|c|}
\hline $\begin{array}{l}\text { Trade Name and } \\
\text { Broadcast Rate/ } \\
\text { Acre of Commercial } \\
\text { Product }\end{array}$ & Common Name & Remarks \\
\hline \multicolumn{3}{|r|}{ POST-DIRECTED } \\
\hline $\begin{array}{c}\text { Evik DF } \\
1.25-2.5 \mathrm{lb}\end{array}$ & ametryn & $\begin{array}{l}\text { Good control of grasses and broadleaf weeds. Most effective if weeds are less than } 6 \text { in tall. Apply } \\
\text { as directed spray after the smallest corn is at least } 12 \text { in tall. Do not spray over top of corn. } \\
\text { Use a surfactant at the rate recommended on the label. Do not graze or feed forage to livestock } \\
\text { for } 30 \text { days after application. Can tank-mix with 2,4-D for improved broadleaf weed control. }\end{array}$ \\
\hline $\begin{array}{c}\text { Gramoxone SL } 2.0 \\
1.0-2.0 \mathrm{pt}\end{array}$ & paraquat & $\begin{array}{l}\text { For control of emerged annual grass and broadleaf weeds. Apply as directed, spray after corn } \\
\text { is } 10 \text { in tall. Do not allow spray to contact more than the lower } 3 \text { in of corn plants. Add } 1 \text { qt of a } \\
\text { nonionic surfactant for } 100 \text { gal of spray. Do not mix with liquid fertilizer. Can be tank-mixed with } \\
\text { several herbicides. See label. }\end{array}$ \\
\hline $\begin{array}{l}\text { Lorox DF } \\
1.5-3.0 \mathrm{lb}\end{array}$ & linuron & $\begin{array}{l}\text { Controls most grasses and broadleaf weeds up to } 5 \text { in tall. Apply as a directed spray after corn } \\
\text { is } 15 \text { in tall. Use lower rate for } 2 \text {-in weeds and higher rate for } 5 \text {-in weeds. Do not spray over the } \\
\text { top of corn. Use a surfactant at the rate recommended on the label. Can tank-mix with 2,4-D for } \\
\text { improved broadleaf weed control. }\end{array}$ \\
\hline $\begin{array}{c}\text { 2,4-D amine }{ }^{2} \\
1 \mathrm{pt}\end{array}$ & $2,4-D$ & $\begin{array}{l}\text { Controls broadleaf weeds, cocklebur, pigweed, ragweed, morning glory, and sicklepod } \\
\text { (coffeeweed). Broadcast over the top when corn is spiking to } 8 \text { in tall and weeds are small. Apply } \\
\text { as directed spray to the base of the corn plant to minimize injury after corn reaches a } \\
\text { height of } 8 \text { in. Do not apply when corn is silking or tasseling. Avoid spray drift to nearby sensitive } \\
\text { crops. }\end{array}$ \\
\hline \multicolumn{3}{|c|}{$\begin{array}{l}\text { 'RESTRICTED USE PESTICIDE. WARNING: THE FOLLOWING STATEMENT HAS BEEN ADDED TO THE ATRAZINE LABEL. THIS STATEMENT SHOULD } \\
\text { BE HEEDED BY ALL PROSPECTIVE USERS AND STEPS SHOULD BE TAKEN TO COMPLY WITH THIS LABEL CHANGE. } \\
\text { ATRAZINE IS A CHEMICAL WHICH CAN TRAVEL (SEEP OR LEACH) THROUGH SOIL AND CAN CONTAMINATE GROUND WATER AS A RESULT } \\
\text { OF AGRICULTURAL USE. ATRAZINE HAS BEEN FOUND IN GROUND WATER AS A RESULT OF AGRICULTURAL USE. USERS ARE ADVISED NOT } \\
\text { TO APPLY ATRAZINE WHERE THE WATER TABLE (GROUND WATER) IS CLOSE TO THE SURFACE AND WHERE THE SOILS ARE VERY PERMEABLE, } \\
\text { I.E., WELL-DRAINED SOILS SUCH AS LOAMY SANDS. YOUR LOCAL AGRICULTURAL AGENCIES CAN PROVIDE FURTHER INFORMATION ON THE } \\
\text { TYPE OF SOIL IN YOUR AREA AND THE LOCATION OF GROUND WATER. IN ADDITION, SOME PRODUCT LABEL STATEMENTS INCLUDE AS A } \\
\text { FURTHER QUALIFICATION OF RISKY SOILS, SOILS CONTAINING SINKHOLES, OVER LIMESTONE BEDROCK, SEVERELY FRACTURED SURFACES, AND } \\
\text { SUBSTRATES WHICH WOULD ALLOW DIRECT INTRODUCTION INTO AN AQUIFER. } \\
\text { 'See EDIS fact sheet SS-AGR-12, Florida's Organo-Auxin Herbicide Rule (https://edis.ifas.ufl.edu/wg051), for state rules pertaining to application } \\
\text { of organo-auxin herbicides in Florida. } \\
\text { NOTE: Herbicide recommendations in this report are contingent upon their registration by the EPA. If a registration is canceled, the herbicide } \\
\text { would no longer be recommended. }\end{array}$} \\
\hline
\end{tabular}


Table 3. Postemergence herbicide-tolerant varieties.

\begin{tabular}{|c|c|c|}
\hline $\begin{array}{l}\text { Trade Name and Broadcast } \\
\text { Rate/Acre of Commercial } \\
\text { Product }\end{array}$ & $\begin{array}{l}\text { Common Name (and } \\
\text { Broadcast Rate/Acre of } \\
\text { Active Ingredient) }\end{array}$ & Remarks \\
\hline $\begin{array}{l}\text { Liberty } 280 \\
22 \mathrm{oz} / \mathrm{A}\end{array}$ & glufosinate & $\begin{array}{l}\text { USE ONLY ON LIBERTY LINK CORN HYBRIDS. APPLICATIONS OF LIBERTY } 280 \\
\text { TO NON-TOLERANT HYBRIDS WILL RESULT IN SEVERE CROP INJURY AND/OR } \\
\text { CROP DEATH. Can be applied postemergence from the time of crop emergence } \\
\text { until the corn has reached the V5 stage. Liberty } 280 \text { is a broad-spectrum herbicide } \\
\text { with limited systemic activity. Possesses no soil residual activity. Effective on a } \\
\text { number of grassy weeds including Texas panicum, but grasses must be between } 3 \\
\text { and } 6 \text {-in high for consistent control. Several broadleaf species, particularly morning } \\
\text { glories and volunteer peanuts, are easily controlled with Liberty } 280 \text {. Complete } \\
\text { coverage is essential-use with at least } 20 \text { gal water/acre and flat fan nozzles. } \\
\text { Adding ammonium sulfate at } 17 \text { lb/100 gal will improve herbicide activity. Should } \\
\text { be tank-mixed with atrazine for broader-spectrum and more consistent control. Do } \\
\text { not make more than } 2 \text { applications per season or exceed a total of } 44 \text { oz/A/season. } \\
\text { Applications of Liberty } 280 \text { should be made between dawn and } 2 \text { hours before } \\
\text { sunset for optimum weed control. Rain-free period is } 4 \text { hours. Treated corn can be } \\
\text { harvested for silage within } 60 \text { days after treatment. }\end{array}$ \\
\hline $\begin{array}{l}\text { Sequence } \\
2-2.5 \mathrm{pt} / \mathrm{A}\end{array}$ & $\begin{array}{l}\text { glyphosate }+ \\
\text { metolachlor }\end{array}$ & $\begin{array}{l}\text { For Roundup Ready hybrids only. Sequence can be used for improved control of } \\
\text { tropical spiderwort and Palmer amaranth. Do not exceed } 5 \text { pt/A/yr. Can be tank- } \\
\text { mixed with atrazine. }\end{array}$ \\
\hline $\begin{array}{l}\text { Expert } \\
2.5-3.75 \mathrm{qt} / \mathrm{A}\end{array}$ & $\begin{array}{l}\text { glyphosate }+ \\
\text { metolachlor }+ \\
\text { atrazine }\end{array}$ & $\begin{array}{l}\text { Can be applied preemergence on any corn hybrid or postemergence on Roundup } \\
\text { Ready hybrids only. Can be applied over the top for corn up to } 12 \text { in high. }\end{array}$ \\
\hline $\begin{array}{l}\text { Halex GT } \\
3.6-4 \mathrm{pt} / \mathrm{A}\end{array}$ & $\begin{array}{l}\text { glyphosate }+ \\
\text { metolachlor }+ \\
\text { mesotrione }\end{array}$ & $\begin{array}{l}\text { It is recommended that this product be applied postemergence only, to Roundup } \\
\text { Ready hybrids. Can be applied from corn emergence to } 30 \text { in. Should be applied } \\
\text { with a nonionic surfactant and ammonium sulfate. Can be tank-mixed with atrazine } \\
\text { for broader weed control spectrum. }\end{array}$ \\
\hline $\begin{array}{l}\text { Roundup WeatherMax } \\
16-22 \text { fl oz (44 fl oz/A/yr) } \\
\text { glyphosate (4 lb) } \\
32 \text { fl oz (64 fl oz/A/yr) } \\
\text { glyphosate }(5 \mathrm{lb}) \\
26 \text { fl oz (52 fl oz/A/yr) }\end{array}$ & $\begin{array}{l}\text { glyphosate } \\
(0.75-1.5 \mathrm{lb})\end{array}$ & $\begin{array}{l}\text { FOR USE ONLY ON ROUNDUP READY CORN HYBRIDS. APPLICATIONS OF } \\
\text { GLYPHOSATE TO NON-TOLERANT HYBRIDS WILL RESULT IN SEVERE CROP } \\
\text { INJURY AND/OR CROP DEATH. Can be tank-mixed with atrazine, Dual, Harness, } \\
\text { Harness Xtra, Micro-Tech, Bullet, Partner, or Permit herbicides. Various formulations } \\
\text { of glyphosate are available. Not all formulations of glyphosate are labeled for use } \\
\text { on RR corn hybrids. Refer to the specific product label. Sequence is a premix of } \\
\text { glyphosate + S-metolachlor. Expert is a premix of glyphosate + S-metolachlor + } \\
\text { atrazine. } \\
\text { USE RATE TABLE (lb ae/A): } \\
\text { RR Corn } 2 \\
\text { Normal Rate: } 0.75 \mathrm{lb} \\
\text { Maximum Rate: } 1.12 \mathrm{lb} \\
\text { Maximum Total In-Crop: } 2.25 \mathrm{lb} \\
\text { Application Timing: V8 or } 30 \text { in (up to } 48 \text { in with drop nozzles) } \\
\text { RR Corn } \\
\text { Normal Rate: } 0.75 \mathrm{lb} \\
\text { Maximum Rate: } 0.75 \mathrm{lb} \\
\text { Maximum Total In-Crop: } 1.5 \mathrm{lb} \\
\text { Application Timing: Emergence to V8 or } 30 \text { in }\end{array}$ \\
\hline $\begin{array}{l}\text { Assure II } \\
5-12 \text { oz/A }\end{array}$ & quizalofop & $\begin{array}{l}\text { Apply only to Enlist corn. Do not apply to any other corn varieties; it will result } \\
\text { in corn death. Apply when Enlist corn is at V } 2 \text { to V6 stage. Apply with nonionic } \\
\text { surfactant or NIS }(0.25 \% \mathrm{v} / \mathrm{v}) \text { or crop oil }(1 \% \mathrm{v} / \mathrm{v}) \text {. Follow the label for buffer } \\
\text { requirement. }\end{array}$ \\
\hline $\begin{array}{c}\text { Enlist Duo } \\
3.5-4.75 \mathrm{pt} / \mathrm{A} \\
\text { or } \\
\text { Enlist One } \\
1.5-2 \mathrm{pt} / \mathrm{A}\end{array}$ & $\begin{array}{l}\text { glyphosate }+2,4-D \\
\text { choline } \\
\text { 2,4-D choline }\end{array}$ & $\begin{array}{l}\text { Only for use in Enlist corn and not on other corn varieties. Application can be made } \\
\text { from preplant to up to V } 8 \text { stage or } 30 \text {-in corn height. Do not apply a total of more } \\
\text { than } 14.25 \text { pt of Enlist Duo or more than } 6 \text { pt of Enlist One per season. Read the } \\
\text { label carefully for more essential information and follow the herbicide stewardship } \\
\text { instructions for buffer requirements, nozzle selection, tank-mix partners, spray } \\
\text { application information, and application timing. The label is the law. }\end{array}$ \\
\hline
\end{tabular}


Table 4. Estimated effectiveness of recommended herbicides on common weeds in Florida corn. ${ }^{1}$

\begin{tabular}{|c|c|c|c|c|c|c|c|c|c|}
\hline & Sutan+ & Atrazine & $\begin{array}{c}\text { Dual } \\
\text { Magnum }\end{array}$ & Python & $\begin{array}{l}\text { Pendimax or } \\
\text { Prowl } \\
\text { or } \\
\text { Prowl } \mathrm{H}_{2} \mathrm{O}\end{array}$ & Glyphosate & Atrazine & Callisto & Accent \\
\hline Time of Application & PPI & PRE & PRE & PRE & PRE & РОТ & РОТ & РОT & РOT \\
\hline \multicolumn{10}{|c|}{ WEEDS } \\
\hline \multicolumn{10}{|c|}{ BROADLEAF } \\
\hline Bristly starbur & $\mathrm{P}$ & G & $\mathrm{P}$ & $\mathrm{E}$ & $\mathrm{P}$ & $\mathrm{G}-\mathrm{E}$ & $\mathrm{E}$ & - & $\mathrm{P}$ \\
\hline Cocklebur & $\mathrm{P}$ & $\mathrm{G}-\mathrm{E}$ & $\mathrm{P}$ & G & $\mathrm{P}$ & $\mathrm{E}$ & $\mathrm{E}$ & G & $\mathrm{P}$ \\
\hline Florida beggarweed & $\mathrm{P}$ & $E$ & $\mathrm{~F}-\mathrm{G}$ & $\mathrm{F}-\mathrm{G}$ & $\mathrm{P}$ & G & G & - & $\mathrm{P}$ \\
\hline Florida pusley & $\mathrm{G}-\mathrm{E}$ & $E$ & G-E & $E$ & G-E & $\mathrm{F}$ & $E$ & - & $P$ \\
\hline Morning glories & $\mathrm{F}-\mathrm{G}$ & G & $\mathrm{P}$ & $\mathrm{F}-\mathrm{G}$ & $\mathrm{P}$ & $\mathrm{F}-\mathrm{G}$ & G & $\mathrm{P}-\mathrm{F}$ & $\mathrm{P}$ \\
\hline Pigweed & $\mathrm{G}-\mathrm{E}$ & $\mathrm{E}$ & $\mathrm{E}$ & $\mathrm{E}$ & $\mathrm{G}-\mathrm{E}$ & $\mathrm{E}$ & $\mathrm{E}$ & G & $\mathrm{P}$ \\
\hline Ragweed & $\mathrm{F}$ & $\mathrm{E}$ & $\mathrm{F}$ & G & $\mathrm{P}$ & $\mathrm{G}-\mathrm{E}$ & $\mathrm{E}$ & $\mathrm{F}-\mathrm{G}$ & $\mathrm{P}$ \\
\hline Sicklepod & $\mathrm{F}-\mathrm{G}$ & G & $\mathrm{P}$ & G & $\mathrm{P}$ & $\mathrm{G}-\mathrm{E}$ & $\mathrm{E}$ & - & $\mathrm{P}$ \\
\hline \multicolumn{10}{|c|}{ GRASS } \\
\hline Crabgrass & $E$ & G & $\mathrm{E}$ & $\mathrm{P}$ & $\mathrm{E}$ & $\mathrm{E}$ & $\mathrm{P}$ & $\mathrm{P}$ & $P$ \\
\hline Goosegrass & $\mathrm{E}$ & G & $\mathrm{E}$ & $\mathrm{P}$ & $\mathrm{E}$ & $E$ & $\mathrm{P}$ & $\mathrm{P}$ & $\mathrm{P}$ \\
\hline Johnsongrass (from seed) & $\mathrm{E}$ & $\mathrm{F}$ & $\mathrm{F}$ & $\mathrm{P}$ & $\mathrm{G}-\mathrm{E}$ & $\mathrm{E}$ & $\mathrm{P}$ & $\mathrm{P}$ & $\mathrm{G}-\mathrm{E}$ \\
\hline Sandbur & $\mathrm{E}$ & G & G & $\mathrm{P}$ & $\mathrm{G}-\mathrm{E}$ & G & $\mathrm{P}$ & - & $G-E$ \\
\hline Texas panicum & $\mathrm{G}-\mathrm{E}$ & $\mathrm{P}$ & $\mathrm{P}$ & $\mathrm{P}$ & $\mathrm{G}-\mathrm{E}$ & $\mathrm{E}$ & $\mathrm{F}$ & - & $\mathrm{G}-\mathrm{E}$ \\
\hline Annual ryegrass & - & - & - & $\mathrm{P}$ & - & G & - & - & $\mathrm{G}-\mathrm{E}$ \\
\hline \multicolumn{10}{|c|}{ SEDGE } \\
\hline Purple nutsedge & G & $\mathrm{P}$ & $\mathrm{P}$ & $\mathrm{P}$ & $\mathrm{P}$ & $F-G$ & $\mathrm{P}$ & - & $\mathrm{P}$ \\
\hline Yellow nutsedge & $\mathrm{G}-\mathrm{E}$ & $\mathrm{P}$ & $\mathrm{P}$ & $\mathrm{P}$ & $\mathrm{P}$ & $\mathrm{F}-\mathrm{G}$ & $P$ & - & $P$ \\
\hline \multicolumn{10}{|c|}{$\begin{array}{l}\text { 'Estimated effectiveness based on rates recommended in this report. Effectiveness may vary depending on factors such as herbicide rat } \\
\text { of weeds, time of application, soil, and weather. } \\
\text { Weed Control Symbols: } E=90 \%-100 \% \text { control; G = } 80 \%-90 \% \text { control; F =60\%-80\% control; P = less than } 60 \% \text { control; - = insufficient } \\
\text { observations. } \\
\text { Time of Application Symbols: PPI = Preplant Incorporated; PRE = Preemergence; POT = Postemergence Broadcast. }\end{array}$} \\
\hline
\end{tabular}


Table 5. Estimated effectiveness of recommended herbicides on common weeds in Florida corn (continued). ${ }^{1}$

\begin{tabular}{|c|c|c|c|c|c|c|c|c|c|c|}
\hline Herbicides & Basagran & 2,4-D & Banvel/Clarity & Distinct & Sempra & $\begin{array}{c}\text { Liberty } \\
280\end{array}$ & $\begin{array}{c}\text { Treflan, } \\
\text { Pendimax, } \\
\text { or Prowl }\end{array}$ & Evik & Lorox & Gramoxone \\
\hline $\begin{array}{c}\text { Time of } \\
\text { Application }\end{array}$ & POT & POT & POT & POT & POT & POT & POT & PDS & $\begin{array}{l}\text { POT/ } \\
\text { PDS }\end{array}$ & PDS \\
\hline \multicolumn{11}{|c|}{ WEEDS } \\
\hline \multicolumn{11}{|c|}{ BROADLEAF } \\
\hline Bristly starbur & $E$ & G & G & G-E & G & $\mathrm{G}-\mathrm{E}$ & $\mathrm{P}$ & $\mathrm{E}$ & G & $\mathrm{G}-\mathrm{E}$ \\
\hline Cocklebur & $\mathrm{E}$ & $E$ & $E$ & $\mathrm{E}$ & G & $\mathrm{G}-\mathrm{E}$ & $\mathrm{P}$ & $\mathrm{E}$ & G-E & $E$ \\
\hline $\begin{array}{l}\text { Florida } \\
\text { beggarweed }\end{array}$ & $P$ & $\mathrm{G}$ & $\mathrm{G}$ & $\mathrm{G}$ & $P$ & $\mathrm{G}$ & $\mathrm{P}$ & $E$ & $G$ & G-E \\
\hline Florida pusley & $\mathrm{F}$ & G & G & G & - & $\mathrm{G}-\mathrm{E}$ & $\mathrm{E}$ & G & G & G \\
\hline Morning glories & $F-G$ & $\mathrm{E}$ & $\mathrm{E}$ & $\mathrm{E}$ & $\mathrm{P}-\mathrm{F}$ & $\mathrm{G}-\mathrm{E}$ & $\mathrm{P}$ & $\mathrm{F}-\mathrm{G}$ & G & G \\
\hline Pigweed & G & $\mathrm{E}$ & $\mathrm{E}$ & $\mathrm{E}$ & $F-G$ & G & $P$ & G & $\mathrm{E}$ & G-E \\
\hline Ragweed & $F-G$ & $E$ & $E$ & $E$ & G & G & $\mathrm{P}$ & G-E & $E$ & $\mathrm{G}-\mathrm{E}$ \\
\hline Sicklepod & $\mathrm{P}$ & $E$ & $E$ & $E$ & $\mathrm{P}$ & G & $P$ & G & G-E & G-E \\
\hline \multicolumn{11}{|l|}{ GRASS } \\
\hline Crabgrass & $\mathrm{P}$ & $P$ & $\mathrm{P}$ & $\mathrm{P}$ & $\mathrm{P}$ & $\mathrm{G}-\mathrm{E}$ & $E$ & $\mathrm{~F}-\mathrm{G}$ & G-E & $E$ \\
\hline Goosegrass & $\mathrm{P}$ & $\mathrm{P}$ & $\mathrm{P}$ & $\mathrm{P}$ & $\mathrm{P}$ & $\mathrm{G}-\mathrm{E}$ & $\mathrm{E}$ & G & $\mathrm{G}-\mathrm{E}$ & $\mathrm{E}$ \\
\hline $\begin{array}{l}\text { Johnsongrass } \\
\text { (from seed) }\end{array}$ & $P$ & $P$ & $P$ & $F-G$ & $P$ & $E$ & $\mathrm{G}$ & $\mathrm{P}-\mathrm{F}$ & $E$ & G \\
\hline Sandbur & $\mathrm{P}$ & $\mathrm{P}$ & $\mathrm{P}$ & - & $\mathrm{P}$ & G & G & $\mathrm{E}$ & $E$ & G \\
\hline Texas panicum & $\mathrm{P}$ & $P$ & $\mathrm{P}$ & - & $\mathrm{P}$ & $\mathrm{G}-\mathrm{E}$ & $\mathrm{E}$ & G & G & $E$ \\
\hline Annual ryegrass & $P$ & $P$ & $P$ & - & $\mathrm{P}$ & $F-G$ & $\mathrm{~F}$ & $\mathrm{~F}$ & $\mathrm{~F}$ & $F-G$ \\
\hline \multicolumn{11}{|c|}{ SEDGE } \\
\hline Purple nutsedge & $\mathrm{P}$ & $\mathrm{P}$ & $\mathrm{P}$ & $\mathrm{P}$ & G & $\mathrm{F}$ & $\mathrm{P}$ & $\mathrm{P}$ & G & G \\
\hline Yellow nutsedge & G & $P$ & $P$ & $P$ & G & $\mathrm{F}$ & $\mathrm{P}$ & $\mathrm{P}$ & G & G \\
\hline
\end{tabular}

${ }^{1}$ Estimated effectiveness based on rates recommended in this report. Effectiveness may vary depending on factors such as herbicide rate, size of weeds, time of application, soil, and weather.

Weed Control Symbols: $E=90 \%-100 \%$ control; $G=80 \%-90 \%$ control; $F=60 \%-80 \%$ control; $P=$ less than $60 \%$ control; $-=$ insufficient observations.

Time of Application Symbols: PPI = Preplant Incorporated; PRE = Preemergence; POT = Postemergence Broadcast; PDS = Post-Directed Spray. 